SAFETY AND LABORATORY PRACTICE 
Macmillan Technician Series

P. Astley, Engineering Drawing and Design II

P. J. Avard and J. Cross, Workshop Processes and Materials I

G. D. Bishop, Electronics II

G. D. Bishop, Electronics III

J. Elliott, Building Science and Materials

D. E. Hewitt, Engineering Science II

P. R. Lancaster and D. Mitchell, Mechanical Science III

R. Lewis, Physical Science I

Noel M. Morris, Electrical Principles II

Noel M. Morris, Electrical Principles III 


\section{SAFETY AND LABORATORY PRACTICE}

John G. Ellis Norman J. Riches 
All rights reserved. No part of this publication may be reproduced or transmitted, in any form or by any means, without permission.

First published 1978 by

THE MACMILLAN PRESS LTD

London and Basingstoke

Associated companies in Delhi Dublin

Hong Kong Johannesburg Lagos Melbourne

New York Singapore and Tokyo

\section{British Library Cataloguing in Publication Data}

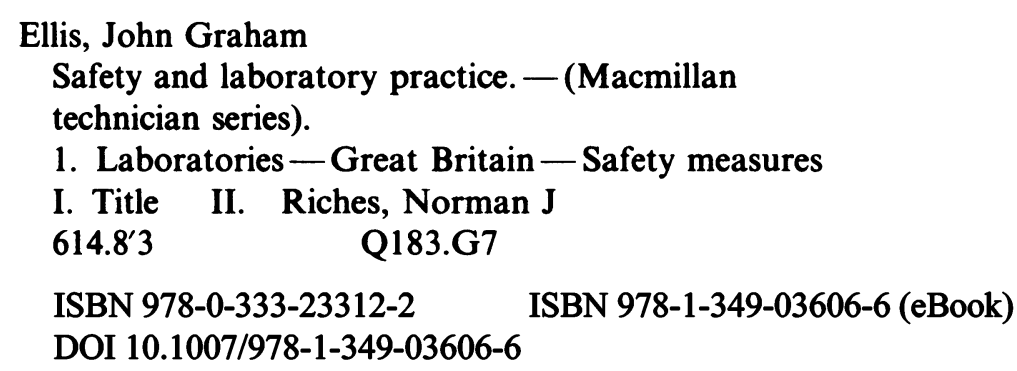

This book is sold subject to the standard conditions of the Net Book Agreement.

The paperback edition of this book is sold subject to the condition that it shall not, by way of trade or otherwise, be lent, resold, hired out, or otherwise circulated without the publisher's prior consent in any form of binding or cover other than that in which it is published and without a similar condition including this condition being imposed on the subsequent purchaser. 


\section{Contents}

\section{Preface}

1 Laboratory First-aid
1.1 Bleeding
1.2 Fractures
1.3 Heat Burns
1.4 Chemical Burns
1.5 Poisoning
1.6 Unconsciousness
1.7 Artificial Respiration
1.8 Heart Massage
1.9 Shock
1.10 Order of Procedure on Discovering a Casualty
1.11 Provision of First-aid Equipment
1.12 Diabetes
1.13 Fits
1.14 Eye Care
1.15 Reporting of Accidents
1.16 Assignments

\section{Electrical Safety}

2.1 Electrical Units

2.1.1 Current

2.1.2 Potential

2.1.3 Resistance

2.1.4 Power

2.2 Effects of an Electric Current

2.3 Correct Wiring of a 13 A Plug Top

2.4 Correct Choice of Fuse

2.5 The Earth Wire and Earthing

2.6 Replacing Equipment Flex

2.7 Use of Distribution Panels and Multiple Adapters

2.8 Mechanical Damage to Electrical Fittings

2.9 The Euro Plug

2.10 Earth Leakage Trips

2.11 Assignments
3 Fire Safety

3.1 Fire Hazards 20

3.2 Fire Extinguishers 22

3.2.1 Main types of fire extinguisher 23

3.3 Fire Precautions 27

3.4 Action on Discovering a Fire 28

3.5 Hazard Warnings 28

3.6 Assignments 30

4 Technicians and the Law 31

4.1 The English Legal System 31

4.2 The Health and Safety at Work, etc., Act, $1974 \quad 32$

4.3 Disposal of Dangerous Substances 35

4.4 Trading Activities 36

4.4.1 Purchase of alcohol 37

4.4.2 Purchase of poisons $\quad 37$

4.4.3 Purchase of goods from abroad 38

4.5 Experiments with Animals 38

4.6 Assignments 38

5 Safety in Chemistry Laboratories 39

5.1 General Precautions 39

5.2 Fume Cupboards $\quad 40$

5.3 Flammable Liquids $\quad 42$

5.4 Dangerous Chemicals 45

5.5 Labelling 47

5.6 Assignments 48

6 Safety in Physics Laboratories 49

6.1 General Precautions 49

6.2 Use of Ionising Radiations 50

6.3 X-ray Sources $\quad 52$

6.4 Optical Hazards $\quad 52$

6.5 High Voltages 53

6.6 Compressed Air and Vacuum Systems 54

6.7 Chemical Hazards $\quad 54$

6.8 Assignments $\quad 55$ 
7 Safety in Biology Laboratories

7.1 General Rules

7.2 Additional Chemical Hazards

7.2.1 Carcinogens

7.2.2 Teratogens

7.2.3 Other toxins

7.2.4 Disinfectants

7.3 Hazards Involving Equipment and Apparatus

7.4 Safety in Microbiology and Pathology Laboratories 7.4.1 Containment of micro-organisms

7.4.2 Protection

7.4.3 Handling human blood

7.5 Safety with Animals in Laboratories and Animal Houses

7.6 Experiments on Humans

7.7 Assignments

8 Scientific Measurement and Reporting

8.1 Accuracy

8.2 Vernier Callipers

8.3 Micrometer Screw Gauges

8.4 Balances

8.5 Volumetric Glassware

8.6 Multimeters

8.7 Microscopes

8.8 Scientific Reporting

8.9 Assignments

9 Laboratory Standards

9.1 Measurement

9.2 Standards

9.3 Use of Standards

9.4 Commonly Available Standards

9.4.1 Physics laboratories

9.4.2 Chemistry laboratories

9.5 The British Standards Institution

9.6 Assignments
Appendix $\quad 85$

SI Units $\quad 85$

General Physical Constants $\quad 86$

Resistivities of Some Metals $\quad 86$

E.M.F. of Some Cells 86

Physical Constants of Some Metals $\quad 87$

Thermoelectric Potentials $\quad 88$

Standard Wire Gauges $\quad 88$

Screw Threads $\quad 89$

Antidotes $\quad 90$

Some Carcinogenic Substances $\quad 90$

Safety Colours and Safety Signs 90

Further Reading $\quad 92$ 


\section{Preface}

Our aim in writing this book has been to provide a useful text for students on courses leading to the Technician Certificate of the Technician Education Council in Sector C; this includes courses in all the sciences, medical laboratory technology, plastics and polymers.

It has been stated that the content of the Level I Standard Unit, or something similar to it, must be studied by most of these students and their knowledge must be assessed. This does not mean that safety must be taught separately from the technical units; indeed, many colleges intend to integrate the teaching of safety and laboratory practice with other units where this is appropriate. We have borne this intention in mind while preparing this book.

In some places we have gone beyond the TEC Standard Unit (U76/001). For example, we have included a chapter on hazards in the biology laboratory, and in the appendix we have included data which we hope will be of permanent value to those who use this book. There will be some students following a TEC programme without regular attendance at college, and we hope that they will find what we have written is useful.

This book will also be of value to those studying the Standard Unit Introduction to Health and Safety at Work (U78/450), a freestanding unit which may be included in a wide variety of programmes.

We have attempted to bear in mind the needs of those technicians who are not following formal TEC courses but nevertheless need to know how to conduct a laboratory safely. There will be those starting work in laboratories somewhat later in life-school part-time laboratory assistants are an obvious group. Many technicians recruited to the fast-growing laboratories in the developing world should find that, with the exception of details of English law, everything we have said applies to them as well.

We would like to thank all those who have helped in many different ways in the writing of this book. We would particularly like to thank John Rowlinson and Geoff Jones, for their considerable help in the preparation of chapters 5 and 7, and Ian Bourne, for his assistance in the preparation of many of the photographs that are reproduced here. 
We also acknowledge the assistance of the following organisations who have allowed us to reproduce copyright material: Association for Science Education, Air Products Ltd, British Oxygen Co. Ltd, Chubb Fire Security Ltd, Griffin and George Ltd, Hopkin and Williams. Extracts from BS 5378 are reproduced by permission of the British Standards Institution, 2 Park Street, London WIA 2BS, from whom complete copies can be obtained.

JOHN G. ELLIS

NORMAN J. RICHES 